\author{
JURNAL EINSTEIN \\ Jurnal Hasil Penelitian Bindang Fisika \\ Available online http://jurnal.unimed.ac.id/2012/index.php/inpafi \\ e-issn: $2407-747 x$, p-issn $2338-1981$
}

\title{
RANCANG BANGUN INSTRUMENTASI ALAT UKUR TEGANGAN LISTRIK PADA LARUTAN ELEKTROLIT MENGGUNAKAN ELEKTRODA BERBASIS PERSONAL COMPUTER (PC) DENGAN ARDUINO UNO R3
}

\author{
Caine Tampubolon dan Abd. Hakim S \\ Jurusan Fisika, Fakultas Matematika dan Ilmu Pengetahuan Alam, Universitas Negeri \\ Medan, Indonesia \\ cainetampubolon@gmail.com \\ Diterima September 2017; Disetujui Oktober 2017; Dipublikasikan November 2017
}

\begin{abstract}
ABSTRAK
Penelitian ini bertujuan untuk membuat sebuah alat ukur tegangan listrik pada elektroda berbasis personal computer (PC) dengan Arduino Uno R3 dengan tujuan untuk membuat listing program alat ukur tegangan listrik pada elektroda yang telah dirancang, serta untuk mengetahui respon alat terhadap output pengukuran yang mampu merekam data hasil pengukuran secara real-time. Dalam penenelitian ini digunakan perangkat keras (hardware) yaitu rangkaian sensor tegangan terdiri dari dua buah resistor dengan spesifikasi $100 \Omega$ dan 10K, Arduino Uno R3, Mikrokontroler ATMega328, LCD dan satu buah laptop sebagai power supply kemudian untuk perangkat lunak (software) yang digunakan yaitu aplikasi voltage level monitoring. Berdasarkan hasil pengujian yang dilakukan yaitu pengukuran tegangan listrik pada elektroda dengan sampel urea $(0,001 \mathrm{M})$, asa cuka $(\mathrm{CH} 3 \mathrm{COOH})(0,1 \mathrm{M})$, natrium klorida $(\mathrm{NaCl})(0,001 \mathrm{M})$, hidrogen klorida $(\mathrm{HCl})$ $(0,001 \mathrm{M})$, mikrokontroler akan menampilkan data hasil pengukuran pada layar LCD berupa nilai ADC, Volt (miliVolt), kemudian akan dikoneksikan pada personal computer (PC) dengan aplikasi voltage level monitoring yang telah dirancang untuk merekam data hasil pengukuran secara real-time dalam bentuk grafik. Tegangan yang dihasilkan dari data hasil pengukuran tersebut mengalami reaksi oksidasi dan reduksi. Pengujian alat yang dirancang terhadap alat ukur listrik standar yang dilakukan yaitu rata-rata persentase kesalahan sebesar 0,25\% dengan nilai korelasinya 0,97. Batas ukur dari alat yang dirancang pada penelitian ini memiliki range dari $0 \mathrm{mV}-5000 \mathrm{mV}$.
\end{abstract}

Kata Kunci : Rangkaian sensor tegangan, Arduino Uno R3, Elektroda (anoda dan katoda).

\section{PENDAHULUAN}

Perkembangan alat ukur tegangan listrik pada saat ini sudah sangat pesat. Untuk alat ukur tegangan listrik yang dipakai saat ini sudah cukup banyak dipasaran baik dari alat ukur analog dan digital yang bersifat portable sehingga data hasil pengukuran dapat diketahui secara langsung, baik alat ukur tegangan listrik DC maupun AC. Energi listrik melalui elektrokimia merupakan salah satu energi listrik alternatif yang dapat dihasilkan dengan memamfaatkan proses reduksi dan oksidasi (Plata, 2010). Pengukuran tegangan listrik pada larutan elektrolit juga menggunakan dua buah 
elektroda (anoda dan katoda). Elektroda Selektif Ion (ESI) merupakan suatu elektroda yang berfungsi sebagai sensor yang akan memberikan respon berupa sinyal terhadap ion tertentu secara selektif (Situmorang, 2010). Pada umunya implementasi pengukuran tegangan listrik pada larutan elektrolit banyak dipakai oleh penggunanya, menggunakan alat ukur standar dengan jenis alat ukur analog maupun digital yang bersifat portable sehingga data hasil pengukuran dapat diketahui secara mudah praktis tetapi tidak dapat dimonitor secara realtime karena energi listrik melalui elektrokimia merupakan salah satu energi listrik alternatif yang dapat dihasilkan dengan memamfaatkan proses reduksi dan oksidasi. Namun dalam penerapanya, pengukuran tegangan listrik membutuhkan instrumen yang dapat mengukur dan merekam data hasil pengukuran secara realtime. Peneliti tertarik untuk membuat alat yang inovatif yaitu sebuah instrumen yang dapat mengukur serta memiliki keakuratan dalam pembacaan dan pengambilan data hasil pengukuran tegangan listrik pada larutan elektrolit serta mampu merekam data hasil pengukuran secara real-time. Penulis akan membuat perancangan alat dengan judul "Rancang Bangun Instrumentasi Alat Ukur Tegangan Listrik Pada Larutan Elektrolit Menggunakan Elektroda Berbasis Personal Computer (PC) Dengan Arduino Uno R3".

\section{METODE PENLITIAN}

Rancangan sistem alat ukur tegangan listrik pada larutan elektrolit menggunakan elektroda :

1. Elektroda (Anoda dan Katoda) berfungsi sebagai sensor yang akan memberikan respon berupa sinyal.

2. Rangkaian sensor tegangan, berfunsi sebagai penerima sinyal, berupa sinyal analog dari elektroda (anoda dan katoda) yang nanti sinyal tersebut akan diolah mikrokontroler.

3. Arduino Uno, berfungsi sebagai pengolahan data analog ke digital dengan mengontrol hasil pedeteksian yang di terima dari rangkaian sensor tegangan.
4. LCD, berfungsi sebagai penampil dan pemberi informasi dari data hasil pengukuran dalam bentuk digital pada pengukuran tegangan listrik dalam satuan miliVolt $(\mathrm{mV})$.

5. Personal Computer (PC) berfunsi sebagai penampil dan pemberi informasi dari data hasil pengukuran tegangan listrik pada larutan elektrolit menggunakan elektroda yang direkam secara real-time dan ditampilkan pada aplikasi voltage level monitoring.

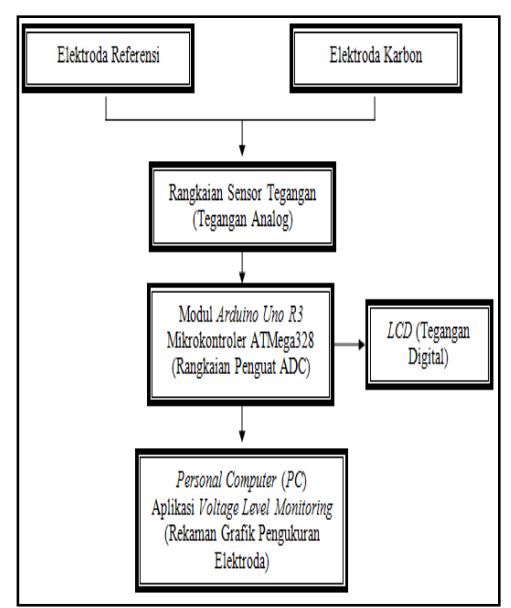

Gambar 1. Diagram Blok Penelitian

1. Pembuatan aplikasi yang digunakan untuk merekam data hasil pengukuran tegangan listrik pada larutan elektrolit adalah dengan menggunakan bahasa C. Data hasil pengukuran tegangan listrik pada elektroda yang didapat akan ditampilkan pada layar LCD (Liquid Crystal Display). Kemudian untuk merekam data hasil pengukuran tersebut akan dilakukan komunikasi antara Arduino Uno R3 dan personal computer (PC) dikoneksikan melalui kabel port USB tipe AB untuk merekam data hasil pengukuran secara real-time yang ditampilkan dalam bentuk grafik pada layar monitor personal computer (PC). 


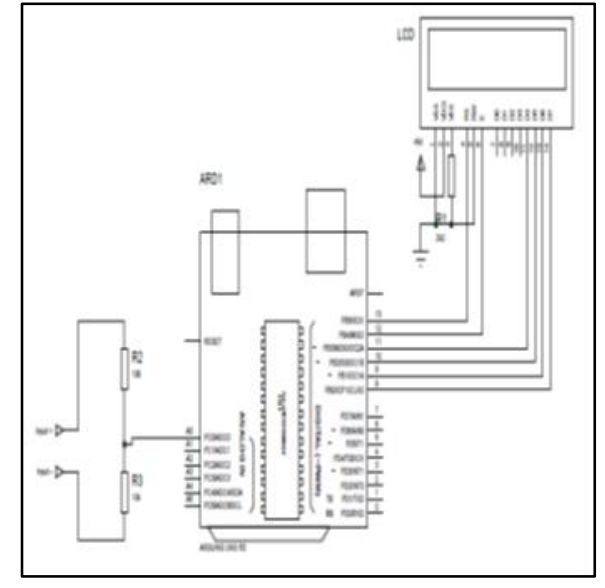

Gambar 2. Skema Rangkaian Alat Ukur Tegangan Listrik Pada Larutan Elektrolit

Gambar 2 merupakan skema rangkaian alat ukur tegangan listrik pada larutan elektrolit. Sinyal analog akan diterima rangkaian sensor tegangan kemudian sinyal analog tersebut akan diolah mikrokontroler tetapi terlebih dahulu sinyal analog diubah menjadi sinyal digital dengan rangkaian ADC. Data hasil pengukuran tegangan listrik pada larutan elektrolit akan ditampilkan pada layar LCD (Liquid Crystal Display) akan menampilkan pengukuran berupa angka pada pengukuran tegangan listrik dalam satuan miliVolt $(\mathrm{mV})$, kemudian data hasil pengukuran tersebut akan ditampilkan pada layar monitor computer personal (PC) dengan sebuah software yang telah diprogram yang dikoneksikan melalui kabel port USB tipe A-B untuk merekam data hasil pengukuran secara real-time yang ditampilkan dalam bentuk grafik. Mengetahui ketepatan pengukuran yang diperoleh oleh alat dengan cara melakukan pengukuran secara manual dengan menggunakan alat ukur listrik lainya, seperti Multimeter Heles UX-866TR untuk memastikan apakah alat berfungsi dengan optimal dan tidak terjadi error instrument.

Persen error dari alat yang diracang menggunakan rumus :

$$
\text { \%error }=\left|\frac{H P A S-H P A R}{H P A S}\right| \times 100 \%
$$

Keterangan :

HPAS = Hasil Pengukuran Alat Standar $\mathrm{HPAR}=$ Hasil Pengukuran Alat yang Dirancang

\section{HASIL DAN PEMBAHASAN}

Rancang bangun instrumentasi alat ukur tegangan listrik pada larutan elektrolit menggunakan elektroda berbasis personal computer (PC) dengan Arduino Uno R3 ini terdiri dari bagian perangkat keras (Hardware) dan perangkat lunak (Software). Perangkat keras (Hardware) yang digunakan terdiri dari rangkaian sensor tegangan, modul Arduino Uno R3 dengan mikrokontroler ATMega328, dua buah elektroda baterai (anoda dan katoda) LCD (Liquid Crystal Display) LCD yang akan digunakan mempunyai lebar display 2 baris 16 kolom atau biasa disebut LCD Character 2x16, dan satu buah laptop ASUS X201E. Perangkat lunak (Software) yang digunakan yaitu bahasa Processing dan bahasa Writing Platform atau yang lebih dikenal dengan bahasa $\mathrm{C}$.

\section{Sistem Kerja Alat}

Pengukuran energi listrik pada larutan elektrolit juga mengunakan dua buah elektroda yaitu elektroda anoda dan katoda. Data hasil pengukuran tersebut masih berupa sinyal analog, sinyal analog inilah yang diterima oleh rangkaian sensor tegangan yang nanti akan diolah mikrokontroler. ADC pada Arduino Uno R3 berfungsi untuk merubah tegangan analog dari sensor menjadi bit yang diinginkan, sehingga data tersebut dapat diolah oleh mikrokontroler ATMega328. Pada layar LCD (Liquid Crystal Display) menampilkan pengukuran berupa angka pada pengukuran tegangan listrik dalam satuan miliVolt $(\mathrm{mV})$, kemudian data hasil pengukuran tersebut akan diampilkan pada layar monitor computer personal (PC) dengan sebuah aplikasi yang telah diprogram yang dikoneksikan melalui kabel port USB tipe A-B untuk merekam data hasil pengukuran secara real-time yang ditampilkan akan pada aplikasi voltage level monitoring grafik. 


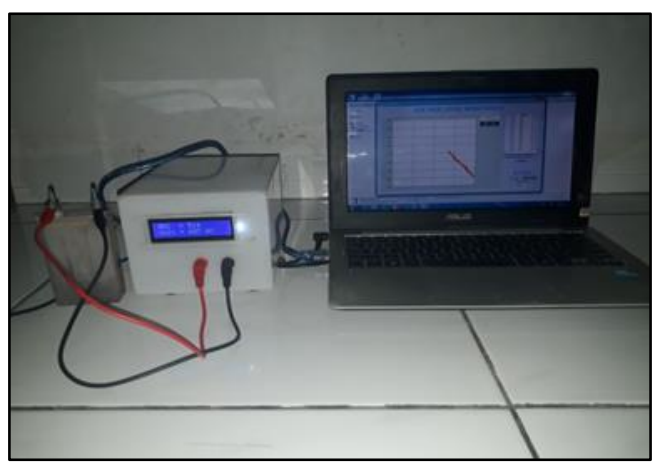

Gambar 3. Bentuk Fisik Alat Ukur Tegangan Listrik Pada Larutan Elektrolit Yang Telah Dirancang

\section{Pengukuran Tegangan Elektroda Dalam Larutan} Elektrolit Menggunakan Alat Ukur Standar

Pengukuran tegangan listrik pada larutan elektrolit urea dengan konsentarsi $(0,001 \mathrm{M})$, asa cuka $(\mathrm{CH} 3 \mathrm{COOH})(0,1 \mathrm{M})$, natrium klorida $(\mathrm{NaCl}) \quad(0,001 \mathrm{M})$, hidrogen klorida ( $\mathrm{HCl})$ $(0,001 \mathrm{M})$ juga diukur dengan menggunakan alat ukur standar yaitu Multimeter HELES UX866TR yaitu untuk mengetahui tegangan listrik pada larutan tersebut dalam waktu 5 menit, 10 menit dan 15 menit untuk perbandingan terhadap alat ukur yang telah dirancang. Tabel 1 merupakan data hasil pengukuran tegangan elektroda dalam larutan elektrolit menggunakan alat ukur standar.

Tabel 1. Data Hasil Pengukuran Tegangan Elektroda Dalam Larutan Elektolit Menggunakan Alat Ukur Standar

\begin{tabular}{lllll}
\hline No & Elektrolit & Konsentrasi & Waktu $(\mathrm{S})$ & Tegangan $(\mathrm{mV})$ \\
\hline 1 & Urea & $0,001 \mathrm{M}$ & 5 menit & 599 \\
& & & 10 menit & 591 \\
& & 15 menit & 592 \\
2 & Asam Cuka & \multirow{2}{*}{, $1 \mathrm{M}$} & 5 menit & 956 \\
& & & 10 menit & 944 \\
\multirow{3}{*}{3} & \multirow{2}{*}{ Natrium Klorida } & \multirow{2}{*}{$0,001 \mathrm{M}$} & 15 menit & 941 \\
& & & 10 menit & 568 \\
& & & 15 menit & 562 \\
4 & Hidrogen Klorida & \multirow{2}{*}{$0,001 \mathrm{M}$} & 5 menit & 503 \\
& & & 10 menit & 495 \\
& & & 15 menit & 483 \\
\hline
\end{tabular}

Hasil Pengukuran Tegangan Elektroda dalam Larutan Elektolit Menggunakan Alat yang Telah Dirancang

Dalam penelitian ini pengujian alat ukur tegangan listik pada larutan elektrolit yaitu dengan mengunakan elektroda dari batu baterai basa yang terdiri dari kutub anoda dan kutub katoda, dan dengan bahan elektrolit urea dengan konsentarsi $(0,001 \mathrm{M})$, asa cuka $(\mathrm{CH} 3 \mathrm{COOH})$
$(0,1 \mathrm{M})$, natrium klorida $(\mathrm{NaCl}) \quad(0,001 \mathrm{M})$, hidrogen klorida $(\mathrm{HCl}) \quad(0,001 \mathrm{M})$. Urea merupakan senyawa organik yang tersusun dari karbon, hidrogen, oksigen, dan nitrogen dengan rumus $\mathrm{CON} 2 \mathrm{H} 4$ atau (NH2)2CO. Berikut ini adalah hasil pengujian alat ukur tegangan listrik pada larutan elektrolit dalam 3 kali pengukuran yaitu selama 5 menit, 10 menit, dan 15 menit.

Pengukuran Tegangan Listrik Pada Elektroda Tanpa Menggunakan Larutan Elektrolit

Pengukuran pertama pada pengujian alat ukur tegangan listrik menggunakan elektroda Anoda dan Katoda yaitu tanpa menggunakan larutan elektrolit. Pengujian ini dilakukan untuk melihat apakah alat yang telah dirancang berjalan dengan baik atau tidak serta mangetahui respon alat terhadap pengukuran yang dilakukan baik menggunakan elektrolit ataupun tidak menggunakan larutan elektrolit. Data hasil pengukuran tegangan listrik pada elektroda tanpa menggunakan larutan elektrolit yaitu tidak ada tegangan listrik yang dihasilkan selama proses pengukuran berlangsung. Gambar 4 merupakan data hasil pengukuran tegangan listrik yang direkam pada aplikasi voltage level monitoring tanpa menggunakan larutan elektrolit.

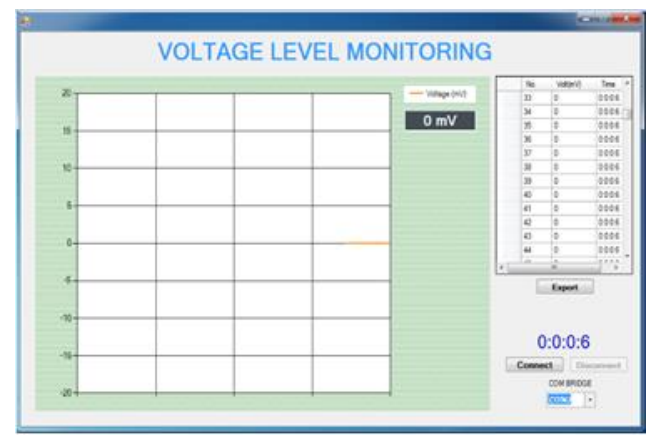

Gambar 4. Data hasil pengukuran tegangan listrik pada aplikasi voltage level monitoring tanpa mennggunakan larutan elektrolit di

\section{Larutan Elektrolit Urea (0,001M)}

Pengukuran Tegangan Listrik Pada Larutan Elektrolit Urea (0,001M) Selama 5 Menit

Pengukuran pertama pada pengujian alat ukur tegangan listrik pada larutan elektrolit urea $(0,001 \mathrm{M})$ seperti yang ditunjukkan pada Gambar 5 merupakan tampilan tegangan elektroda terhadap waktu menggunakan voltage level monitoring dalam larutan elektrolit urea 
$(0,001 \mathrm{M}) \quad$ dari $\quad 0: 4: 6: 2$ sampai 0:4:57:4, sebenarnya dari 0:0:0:2 sampai 0:5:3 Pada Gambar 6 merupakan tampilan grafik tegangan elektroda terhadap waktu menggunakan excel dari 0:4:6:2 sampai 0:4:57:4, sebenarnya dari 0:0:0:2 sampai 0:5:3:6. Seperti Gambar 7 menunjukkan grafik pengukuran tegangan sel potensiometri dalam larutan elektolit urea $(0,001 \mathrm{M}) \quad$ dari $\quad 0: 0: 0: 2$ sampai 0:4:45:8 sebenarnya dari 0:0:0:2 sampai 0:5:3:6. Adapun data hasil pengukuran tegangan listrik pada larutan elektrolit tersebut dilakukan secara realtime yaitu setiap 200 sekon.

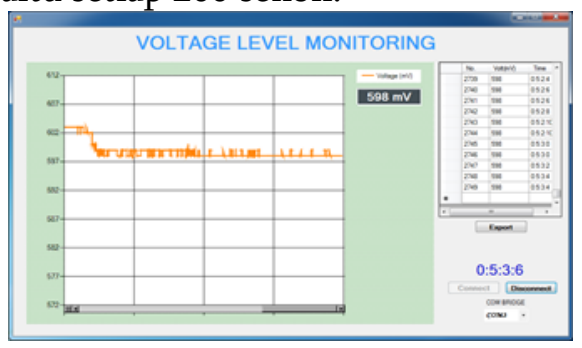

Gambar 5. Tampilan tegangan elektroda terhadap waktu menggunakan voltage level monitoring dalam larutan elektolit urea $(0,001 \mathrm{M})$ dari 0:4:6:2 sampai 0:4:57:4 sebenarnya dari 0:0:0:2 sampai 0:5:3:6

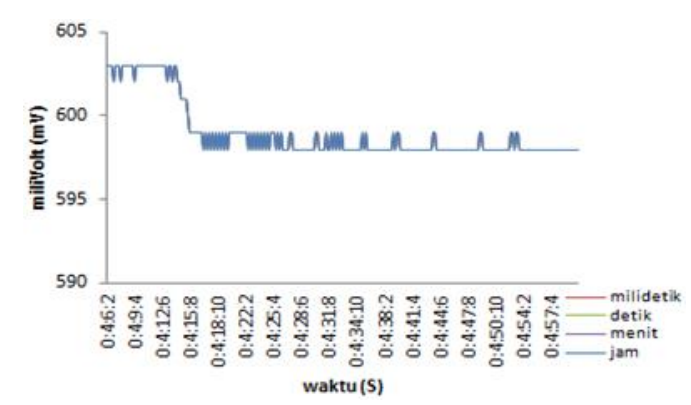

Gambar 6. tampilan grafik tegangan elektroda terhadap waktu menggunakan excel dalam larutan elektolit urea $(0,001 \mathrm{M})$ dari 0:4:6:2 sampai 0:4:57:4 sebenarnya dari 0:0:0:2sampai 0:5:3:6

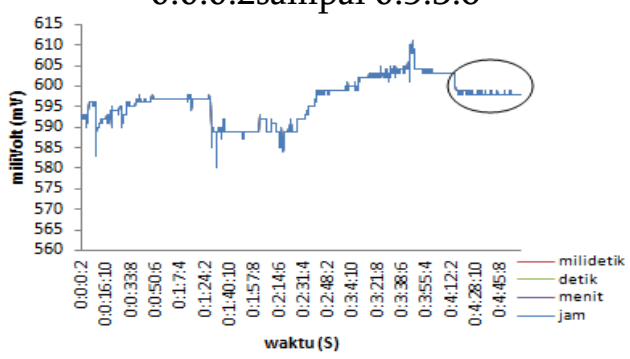

Gambar 7. Grafik pengukuran tegangan sel potensiometri dalam larutan elektolit urea

$(0,001 \mathrm{M})$ dari 0:0:0:2 sampai 0:4:45:8 sebenarnya dari 0:0:0:2 sampai 0:5:3:6

\section{Pengukuran Tegangan Listrik Pada Elektrolit Urea (0,001M) Selama 10 Menit}

Pengukuran kedua pada pengujian alat ukur tegangan listrik pada larutan elektrolit urea $(0,001 \mathrm{M})$ seperti yang ditunjukkan pada Gambar 8 merupakan tampilan tegangan elektroda terhadap waktu menggunakan voltage level monitoring dalam larutan elektolit urea $(0,0001 \mathrm{M})$ dari 0:9:6:2 sampai 0:9:57:4, sebenarnya dari 0:0:0:2 sampai 0:10:8:10. Pada Gambar 9 merupakan tampilan grafik tegangan elektroda terhadap waktu menggunakan excel dalam larutan elektrolit urea $(0,001 \mathrm{M})$ dari 0:9:6:2 sampai 0:9:57:4, sebenarnya dari 0:0:0:2 sampai 0:10:8:10. Pada Gambar 10 Grafik pengukuran tegangan sel potensiometri dalam larutan elektolit urea $(0,001 \mathrm{M})$ dari 0:0:0:2 sampai 0:9:26:6 sebenarnya dari 0:0:0:2 sampai $0: 10: 8: 10$.

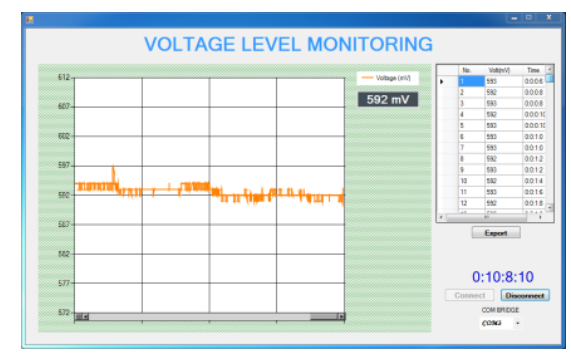

Gambar 8. Tampilan tegangan elektroda terhadap waktu menggunakan voltage level monitoring dalam larutan elektolit urea $(0,0001 \mathrm{M})$ dari 0:9:6:2 sampai 0:9:57:4 sebenarnya dari 0:0:0:2 sampai 0:10:8:10

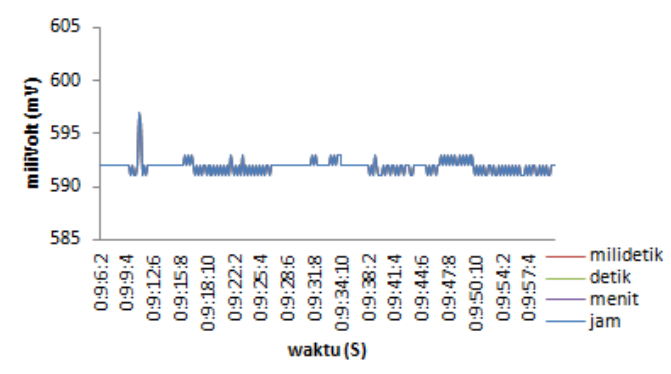

Gambar 9. Tampilan grafik tegangan elektroda terhadap waktu menggunakan excel dalam larutan elektolit urea $(0,001 \mathrm{M})$ dari 0:9:6:2 sampai 0:9:57:4 sebenarnya dari 0:0:0:2 sampai $0: 10: 8: 10$ 


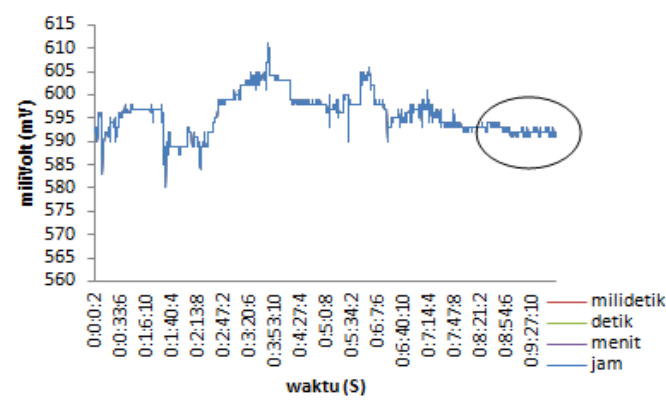

Gambar 10. Grafik pengukuran tegangan sel potensiometri dalam larutan elektolit urea $(0,001 \mathrm{M})$ dari 0:0:0:2 sampai 0:9:26:6, sebenarnya dari 0:0:0:2 sampai 0:10:8:10

\section{Pengukuran Tegangan Listrik Pada Elektrolit Urea (0,001M) Selama 15 Menit}

Pengukuran ketiga pada pengujian alat ukur tegangan listrik pada larutan elektrolit urea $(0,001 \mathrm{M})$ seperti yang ditunjukkan pada Gambar 11 merupakan tampilan tegangan elektroda terhadap waktu menggunakan voltage level monitoring dalam larutan elektrolit urea $(0,001 \mathrm{M})$ dari 0:14:6:2 sampai 0:14:57:4, sebenarnya dari 0:0:0:2 sampai 0:15:19:8. Pada Gambar 12 merupakan tampilan grafik tegangan elektroda terhadap waktu menggunakan excel dari 0:14:6:2 sampai 0:14:57:4, sebenarnya dari 0:0:0:2 sampai 0:15:19:8. Seperti Gambar 13. Grafik pengukuran tegangan sel potensiometri dalam larutan elektolit urea $(0,001 \mathrm{M})$ dari 0:0:0:2 sampai 0:14:13:6, sebenarnya dari 0:0:0:2 sampai 0:15:19:8. Tegangan listrik pada larutan tersebut semakin stabil yang artinya jika pengukuran tersebut dilakukan dengan waktu yang lebih lama maka tegangan listrik pada larutan tersebut semakin stabil.

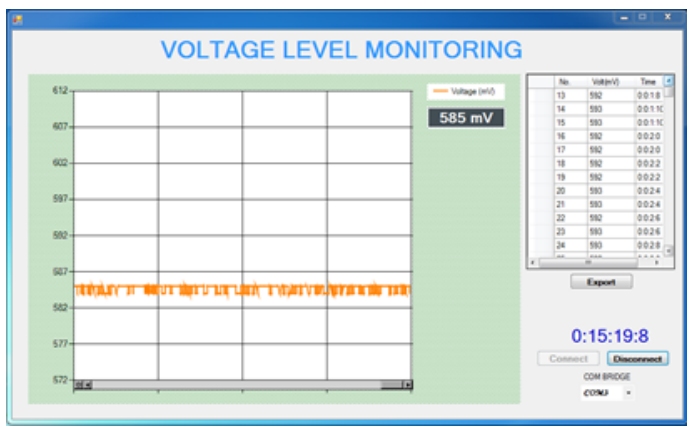

Gambar 11. Tampilan tegangan elektroda terhadap waktu menggunakan voltage level monitoring dalam larutan elektrolit urea $(0,001 \mathrm{M})$ dari 0:14:6:2 sampai 0:14:57:4 sebenarnya dari 0:0:0:2 sampai 0:15:19:8

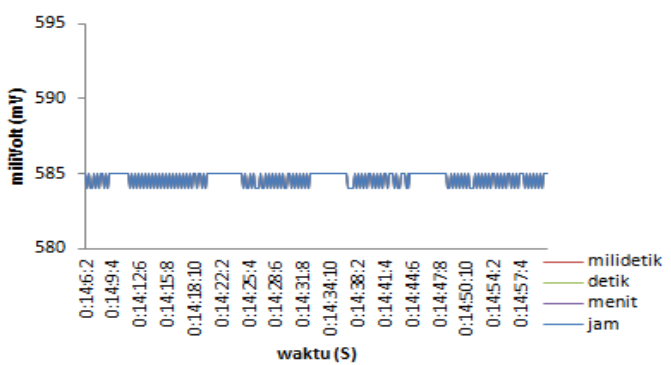

Gambar 12. Tampilan tegangan elektroda terhadap waktu menggunakan excel dalam larutan elektolit urea $(0,001 \mathrm{M})$ dari 0:14:6:2 sampai 0:14:57:4 sebenarnya dari 0:0:0:2 sampai 0:15:19:8

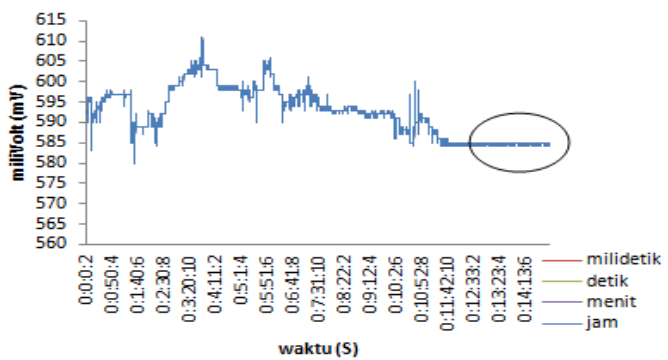

Gambar 13. Grafik pengukuran tegangan sel potensiometri dalam larutan elektolit urea

$(0,001 \mathrm{M})$ dari 0:0:0:2 sampai 0:14:13:6 sebenarnya dari 0:0:0:2 sampai 0:15:19:8

\section{Larutan Elektrolit Asam Cuka (0,1M) \\ Pengukuran Tegangan Listrik Pada Larutan Elektrolit Asa Cuka (CH3COOH) (0,1M) Selama 5 Menit}

Pengukuran pertama pada pengujian alat ukur tegangan listrik pada larutan elektrolit asam cuka (CH3COOH) $(0,1 \mathrm{M})$ seperti yang ditunjukkan pada Gambar 14 merupakan tampilan tegangan elektroda terhadap waktu menggunakan voltage level monitoring dalam larutan elektrolit asam cuka $(0,1 \mathrm{M})$ dari 0:4:6:2 sampai 0:4:57:4, sebenarnya dari 0:0:0:2 sampai 0:5:20:4. Pada Gambar 15 merupakan tampilan grafik tegangan elektroda terhadap waktu menggunakan excel dari 0:4:6:2 sampai 0:4:57:4, sebenarnya dari 0:0:0:2 sampai 0:5:20:4. Seperti Gambar 16. menunjukkan grafik pengukuran tegangan sel potensiometri dalam larutan elektrolit asam cuka $(0,1 \mathrm{M})$ dari 0:0:0:2 sampai 0:4:45:6 sebenarnya dari 0:0:0:2 sampai 0:5:20:4. Tegangan listrik pada larutan elektrolit tersebut belum stabil dan lebih banyak mengalami reaksi oksidasi yang membuat tegangan semakin lama semakin naik. 


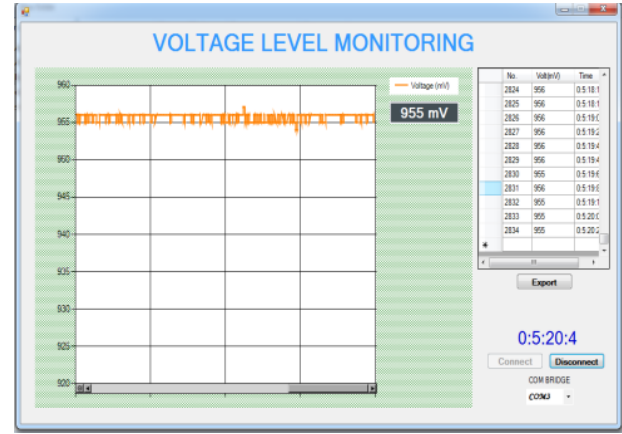

Gambar 14. Tampilan tegangan elektroda terhadap waktu menggunakan voltage level monitoring dalam larutan elktrolit asam cuka $(0,1 \mathrm{M})$ dari 0:4:6:2 sampai $0: 4: 57: 4$ sebenarnya dari 0:0:0:2 sampai 0:5:20:4

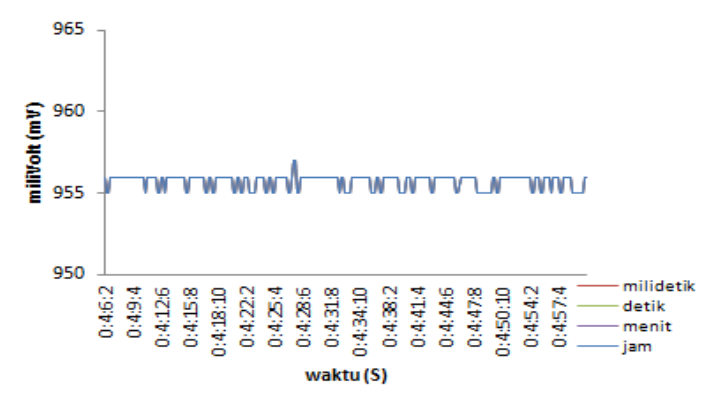

Gambar 15. Tampilan tegangan elektroda terhadap waktu menggunakan excel dalam larutan elektolit asam cuka $(0,1 \mathrm{M})$ dari 0:4:6:2 sampai 0:4:57:4 sebenarnya dari 0:0:0:2 sampai 0:5:20:4

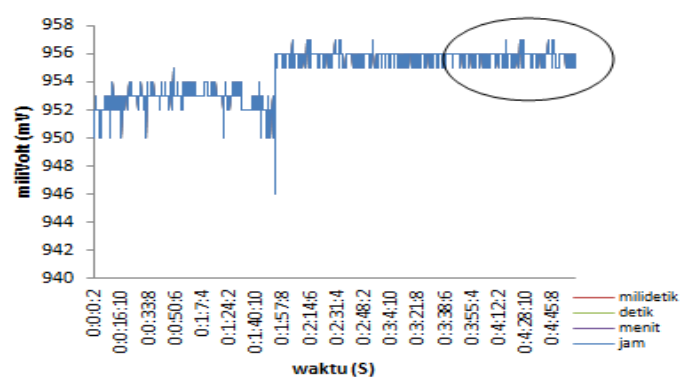

Gambar 16. Grafik pengukuran tegangan sel potensiometri dalam larutan elektrolit asam cuka $(0,1 \mathrm{M})$ dari 0:0:0:2 sampai 0:4:45:6 sebenarnya dari 0:0:0:2 sampai 0:5:20:4

\section{Pengukuran Tegangan Listrik Pada Larutan Elektrolit Asa Cuka (CH3COOH) (0,1M) Selama 10 Menit}

Pengukuran kedua pada pengujian alat ukur tegangan listrik pada larutan elektrolit asam cuka (CH3COOH) $(0,1 \mathrm{M})$ seperti yang ditunjukkan pada Gambar 17 merupakan tampilan tegangan elektroda terhadap waktu menggunakan voltage level monitoring dalam larutan elktrolit asam cuka $(0,1 \mathrm{M})$ dari 0:9:6:2 sampai 0:9:57:4, sebenarnya 0:0:0:2 sampai 0:10:32:0. Pada Gambar 18 merupakan tampilan grafik tegangan elektroda terhadap waktu menggunakan excel dari 0:9:6:2 sampai 0:9:57:4, sebenarnya 0:0:0:2 sampai 0:10:32:0. Seperti Gambar 19. menunjukkan grafik pengukuran tegangan sel potensiometri dalam larutan elektrolit asam cuka $(0,1 \mathrm{M})$ dari 0:0:0:2 sampai 0:9:27:10, sebenarnya 0:0:0:2 sampai 0:10:32:0.

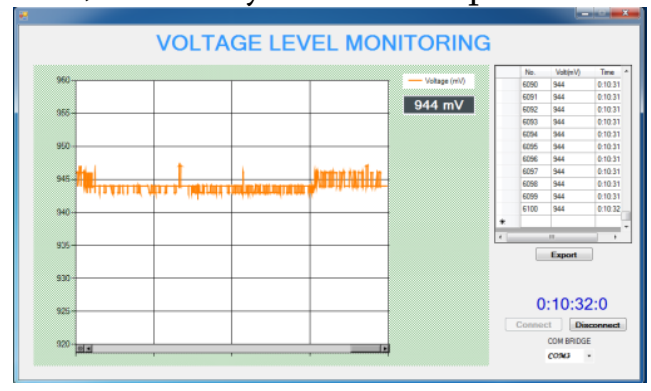

Gambar 17. Tampilan tegangan elektroda terhadap waktu menggunakan voltage level monitoring dalam larutan elektrolit asam cuka $(0,1 \mathrm{M})$ dari 0:9:6:2 sampai 0:9:57:4 sebenarnya 0:0:0:2 sampai 0:10:32:0

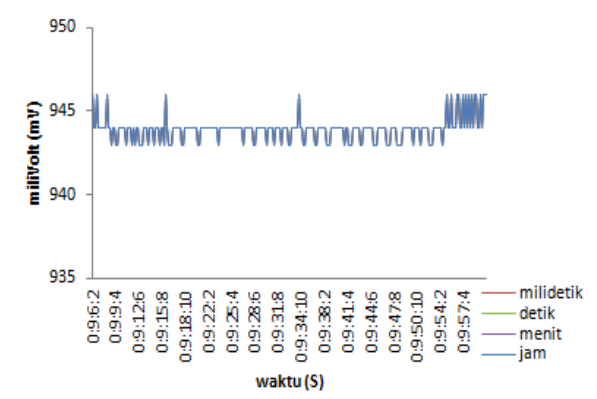

Gambar 18. Tampilan tegangan elektroda terhadap waktu menggunakan excel dalam larutan elektrolit asam cuka $(0,1 \mathrm{M})$ dari 0:9:6:2 sampai 0:9:57:4 sebenarnya 0:0:0:2 sampai 0:10:32:0

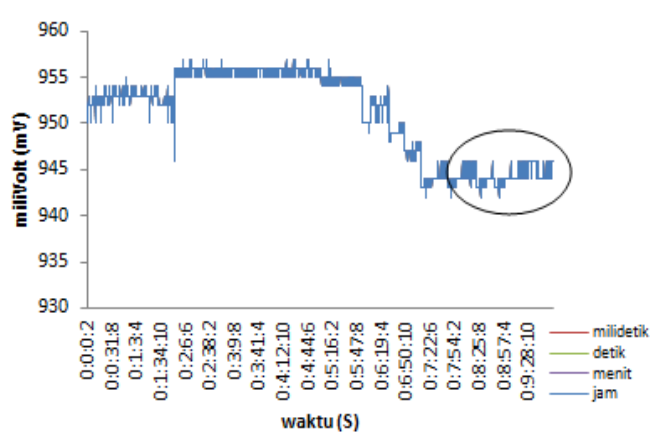


Gambar 19. Grafik pengukuran tegangan sel potensiometri dalam larutan elektrolit asam cuka $(0,1 \mathrm{M})$ dari 0:0:0:2 sampai 0:9:27:10 sebenarnya 0:0:0:2 sampai 0:10:32:0

\section{Pengukuran Tegangan Listrik Pada Larutan Elektrolit Asa Cuka (CH3COOH) (0,1M) Selama 15 Menit}

Pengukuran ketiga pada pengujian alat ukur tegangan listrik pada larutan elektrolit asa cuka $\quad(\mathrm{CH} 3 \mathrm{COOH}) \quad(0,1 \mathrm{M})$ seperti yang ditunjukkan pada Gambar 20 merupakan tampilan tegangan elektroda terhadap waktu menggunakan voltage level monitoring dalam larutan elektrolit asam cuka $(0,1 \mathrm{M})$ dari 0:14:6:2 sampai 0:14:57:4, sebenarnya dari 0:0:0:2 sampai 0:15:42:4. Pada Gambar 21 merupakan tampilan grafik tegangan elektroda terhadap waktu menggunakan excel dari 0:14:6:2 sampai 0:14:57:4, sebenarnya dari 0:0:0:2 sampai 0:15:42:4. Seperti Gambar 22. menunjukkan Grafik pengukuran tegangan sel potensiometri dalam larutan elektrolit asam cuka $(0,1 \mathrm{M})$ dari 0:0:0:2 sampai 0:14:13:6 sebenarnya dari 0:0:0:2 sampai 0:15:42:4. Tegangan tersebut masih belum stabil karena mengalami reaksi oksidasi dan reduksi, dan tegangan semakin lama semakin menurun.

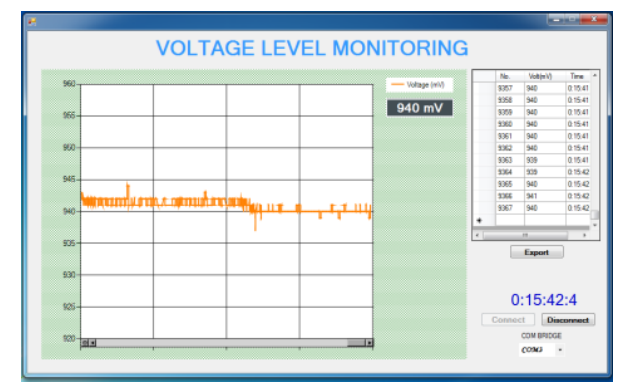

Gambar 20. Tampilan tegangan elektroda terhadap waktu menggunakan voltage level monitoring dalam larutan elektrolit asam cuka $(0,1 \mathrm{M})$ dari 0:14:6:2 sampai

$0: 14: 57: 4$ sebenarnya dari 0:0:0:2 sampai 0:15:42:4

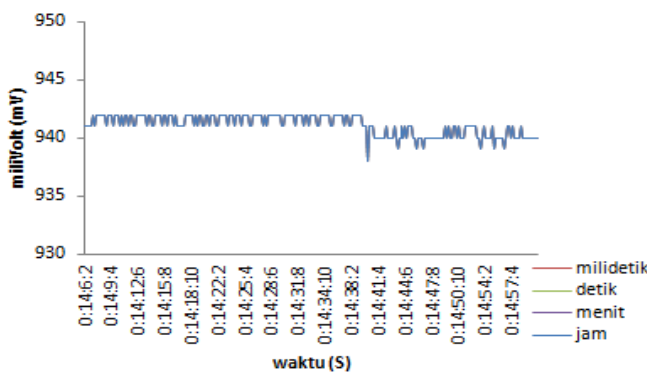

Gambar 21. Tampilan tegangan elektroda terhadap waktu menggunakan excel dalam larutan elektrolit asam cuka $(0,1 \mathrm{M})$ dari 0:14:6:2 sampai 0:14:57:4 sebenarnya dari 0:0:0:2 sampai 0:15:42:4

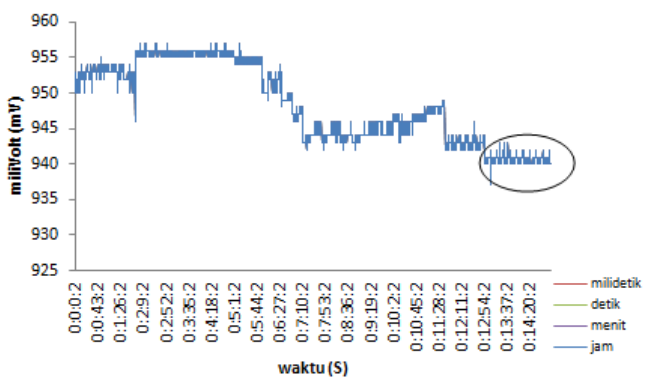

Gambar 22. Grafik pengukuran tegangan sel potensiometri dalam larutan elektrolit asam cuka $(0,1 \mathrm{M})$ dari 0:0:0:2 sampai 0:14:13:6 sebenarnya dari 0:0:0:2 sampai 0:15:42:4

\section{Pengukuran Tegangan Elektroda Dalam Larutan Elektrolit Menggunakan Elektroda Wolfram}

Pengukuran tegangan elektroda dalam larutan elektrolit salah satunya menggunakan elektroda wolfram. Las TIG (tungsten inert gas) atau disebut juga pengelasan menggunakan elektroda wolfram dengan logam pengisi, dan las MIG (metal inert gas) atau disebut juga pengelasan menggunakan elektroda terumpan. Potensiometri merupakan alat yang digunakan untuk mengukur tegangan listrik pada larutan elektrolit menggunakan elektroda wolfram. Data hasil pengukuran tegangan elektroda dalam larutan elektrolit menggunakan alat ukur potensiometri akan ditampilkan pada layar monitor computer personal (PC) untuk merekam data hasil pengukuran secara realtime. Data hasil pengukuran tersebut berupa grafik sinyal tegangan elektroda. Pada Gambar 23 merupakan data hasil pengukuran tegangan elektroda menggunakan elektroda wolfram dengan alat ukur potensiometri. 


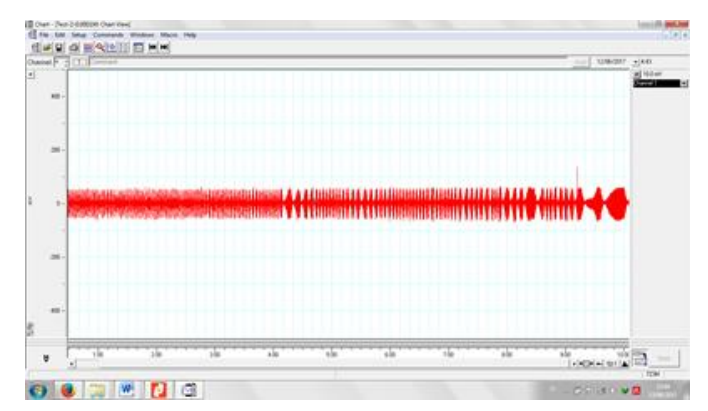

Gambar 23. Data hasil pengukuran tegangan elektroda menggunakan elektroda wolfram dengan alat ukur potensiometri

\section{Pengujian Alat yang Dirancang Terhadap Alat Ukur listrik Standar}

Pengujian ini dilakukan untuk menguji alat yang telah dirancang, untuk menentukan tingkat keakurasian pembacaan alat ukur yang dirancang dan menghitung tingkat persentase kesalahan (error) terhadap alat ukur listrik standar yang ada di Laboratoruim Fisika UNIMED. Alat ukur listrik standar yang digunakan untuk perbandingan yaitu Multimeter Heles UX-866TR. Pengujian ini dilakukan pada tegangan baterai yaitu pada tegangan $1,5 \mathrm{~V}, 3 \mathrm{~V}$, dan $4,5 \mathrm{~V}$ dalam waktu sesaat. Hasil pengujian HPAS dengan HPAR dalam waktu sesaat dapat dilihat pada tabel 2 berikut ini. Gambar 24 merupakan grafik perbandingan HPAS dengan HPAR dalam waktu sesaat.

Tabel 2. Data hasil pengujian HPAS dengan HPAR dalam waktu sesaat

\begin{tabular}{|c|c|c|c|c|c|c|c|c|}
\hline \multirow[b]{2}{*}{ No } & \multirow{2}{*}{$\begin{array}{l}\text { HPAS } \\
\text { (Volt) }\end{array}$} & \multicolumn{5}{|c|}{ Hasil Pengukuran Alat (Volt) } & \multirow{2}{*}{$\begin{array}{l}\text { Rata-rata } \\
\text { Pengukuran } \\
\text { (Volt) }\end{array}$} & \multirow{2}{*}{$\begin{array}{c}\text { Persentase } \\
\text { Kesalahan } \\
(\%)\end{array}$} \\
\hline & & I & II & III & IV & $\mathrm{V}$ & & \\
\hline 1 & 1,5 & 1,502 & 1,501 & 1,502 & 1,501 & 1,503 & 1,5018 & 0,12 \\
\hline 2 & 3 & 3,01 & 3,03 & 3,03 & 3,01 & 3,01 & 3,018 & 0,6 \\
\hline 3 & 4,5 & 4,501 & 4,503 & 4,502 & 4,501 & 4,501 & 4,501 & 0,05 \\
\hline \multicolumn{8}{|c|}{ Rata-rata Persentase Kesalahan Pengukuran } & 0,25 \\
\hline
\end{tabular}

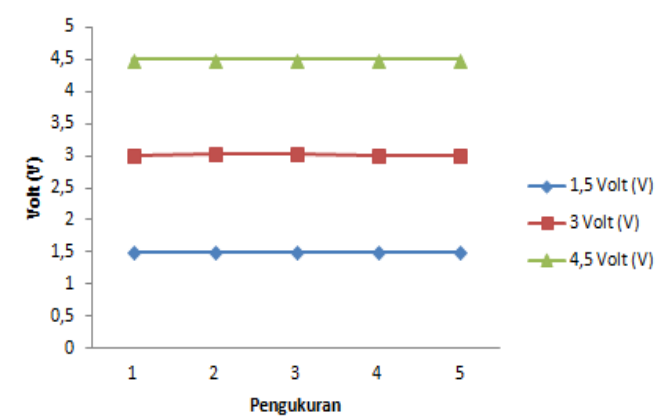

Gambar 24. Grafik perbandingan HPAS dengan HPAR dalam waktu sesaat
Tabel 3. Data Hasil Pengukuran Tegangan Elektroda pada Larutan Elektolit Dalam Keadaan Setimbang

\begin{tabular}{|c|c|c|c|c|c|c|c|}
\hline No & Elektrolit & $\begin{array}{c}\text { Waktu } \\
\text { (S) }\end{array}$ & $\begin{array}{c}\text { Tegangan } \\
(\mathrm{mV})\end{array}$ & $\begin{array}{l}\text { Waktu } \\
\text { (S) }\end{array}$ & $\begin{array}{c}\text { Tegangan } \\
(\mathrm{mV})\end{array}$ & $\begin{array}{l}\text { Waktu } \\
\text { (S) }\end{array}$ & $\begin{array}{c}\text { Tegangan } \\
(\mathrm{mV})\end{array}$ \\
\hline 1 & Urea & 5 menit & 598 & 10 menit & 592 & 15 menit & 585 \\
\hline \multirow[t]{2}{*}{2} & Asam & & & & & & \\
\hline & Cuka & & 956 & & 944 & & 941 \\
\hline \multirow[t]{2}{*}{3} & Natrium & & & & & & \\
\hline & Klorida & & 568 & & 564 & & 554 \\
\hline \multirow[t]{2}{*}{4} & Hidrogen & & & & & & \\
\hline & Klorida & & 502 & & 495 & & 487 \\
\hline
\end{tabular}

Tabel 3 merupakan data hasil pengukuran tegangan elektroda pada larutan elektrolit dalam keadaan setimbang dalam waktu 5 menit, 10 menit dan 15 menit.

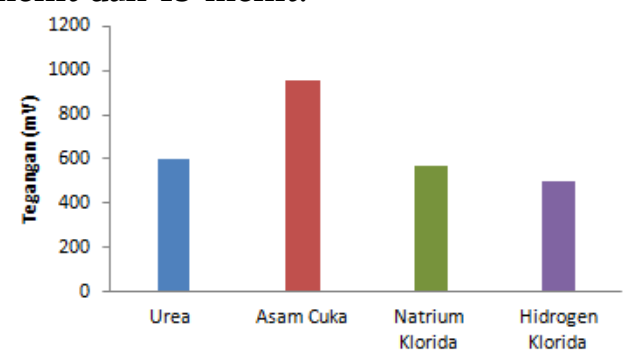

Gambar 25. Grafik hasil pengukuran tegangan elektroda pada larutan elektolit dalam keadaan setimbang dalam waktu 5 menit

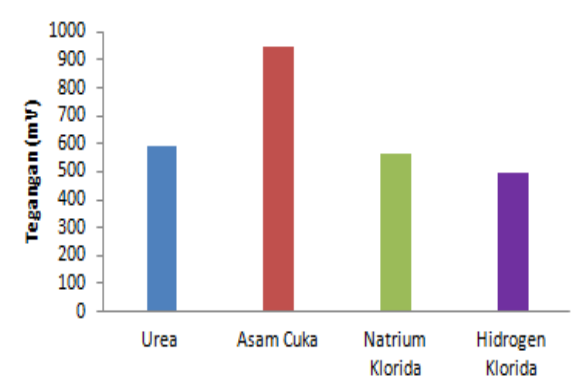

Gambar 26. Grafik hasil pengukuran tegangan elektroda pada larutan elektolit dalam keadaan setimbang dalam waktu 10 menit

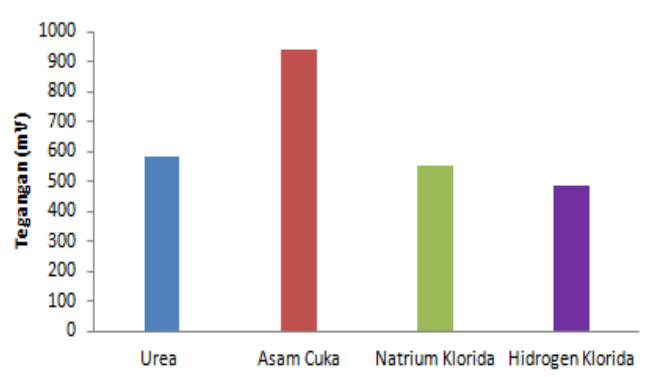

Gambar 27. Grafik hasil pengukuran tegangan elektroda pada larutan elektolit dalam keadaan setimbang dalam waktu 15 menit

Berdasarkan hasil pengujian yang dilakukan untuk menguji alat yang telah dirancang terhadap alat ukur listrik standar 
mempunyai tingkat kesalahan yang cukup kecil. Adanya kesalahan dimungkinkan karena adanya tegangan offset dan noise pada pengukuran rangkaian pengondisi sinyal serta desain mekanik yang hanya terdisi dari satu sensor (Khakim, 2015). Berdasarkan data hasil pengukuran pada tabel 4.2 diketahui bahwa rata-rata tingkat kesalahan (error) ditampilkan pada LCD adalah sebesar $0,25 \%$ dengan nilai korelasi yang didapat yaitu 0,97 (Sudjana, 2005).

\section{KESIMPULAN DAN SARAN}

Setelah dilakukan pembuatan alat ukur tegangan pada larutan elektrolit, kemudian melakukan pengujian alat, maka dapat diambil kesimpulan :

1. Rancang bangun instrumentasi alat ukur tegangan listrik pada larutan elektrolit menggunakan elektroda berbasis personal computer (PC) dengan Arduino Uno R3 berhasil dibuat dengan hasil yang baik. Data hasil pengukuran akan ditampilkan pada LCD berupa nilai ADC, Volt (miliVolt), kemudian dikoneksikan pada personal computer (PC) dengan aplikasi voltage level monitoring yang akan direkam secara real-time.

2. Alat ukur yang telah dirancang sudah bisa menunjukkan tegangan elektroda dari setiap larutan elektrolit yang berbeda konsentrasi. Kalibrasi alat ukur yang dirancang dengan alat ukur standar dalam 3 kondisi yaitu $1,5 \mathrm{~V}, 3 \mathrm{~V}$, dan $4,5 \mathrm{~V}$ tidak berbeda dalam kondisi sesaat.

3. Pengujian alat yang dirancang terhadap alat ukur listrik standar yang dilakukan yaitu rata-rata persentase kesalahan sebesar $0,25 \%$ dengan nilai korelasinya 0,97 Artinya korelasi antara alat standar dengan alat yang dirancang berkolerasi tinggi dan bentuk hubungannya adalah linear positif. Batas ukur dari alat yang dirancang pada penelitian ini memiliki range dari $0 \mathrm{mV}-5000 \mathrm{mV}$.

Berdasarkan hasil penelitian alat ukur tegangan listrik pada larutan elektrolit ini, peneliti memberikan saran untuk penelitian selanjutnya, yaitu :
1. Perlu diminimize agar aplikasi voltage level monitoring dapat terlihat waktu awal dan waktu akhir.

2. Perlu adanya perbaikan pada bahasa pemrograman pada alat dan aplikasi yang telah dirancang berkaitan dengan pencacah waktu dan konversi cacah waktu.

3. Penambahan Memori Chip bertujuan untuk mempermudah penyimpanan data yang telah diperoleh.

\section{DAFTAR PUSTAKA}

Arduino., (2011), Arduino Manual Documentation and Product Specificatiom, Arduino Official Site.

Arihutomo, M., (2012), Sistem Monotoring Arus Listrik Jala - Jala Menggunakan Power Line Carrier, Jurnal Tehnik ITS, Vol.1, No.1, September 2012, ISSN : 23019271.

Banzi, M., (2008), Getting Started With Arduino, 1 Edition. O’Reilly Media, Inc, Sebastopol, AS.

Bishop, O., (2004), Dasar - dasar Elektronika, Jakarta : Penerbit PT. Gelora Aksara Pratama.

Cooper, D., (1999), Instrumentasi Elektronik dan Tehnik Pengukuran, Jakarta : Penerbit Erlangga.

Fitriandi, A., (2016), Alat Monitoring Arus dan Tegangan Berbasis Mokrokontroler dengan SMS Gateway, Bandar Lampung : Electrician-Jurnal Teknik Elektro Universitas Lampung, Vol.10, No.2, Mei 2016.

Istiyanto, E. J., (2013), Pengantar Elektronika dan Instrumentasi, Yogyakarta: Penerbit ANDI.

Iswanto, (2008). Belajar Mikrokontroler Dengan Bahasa C, Yogyakarta: Penerbit ANDI.

Kurniawan, H. I., Hayat, L., (2014), Alat Ukur Tegangan Arus dan Frekuensi Listrik Arus Bolak-Balik Satu Fasa Berbasis Personal Computer, Techno, Universitas Muhammadiyah Purwekerto, Vol.15, No.1, April 2014, Halaman 21-23, ISSN : 1410-8607. 
Miller, J. C., Miller, J. N., (1991). Statistics for Analytical Chemistry, England : Ellis Horwood, Ltd.

Moris, S. A., (2001), Measurement and Instrumentation Principle. New Delhi: Butterworth-Heinemann.

Naga, S., (2006), Perancangan dan Implementasi Alat Ukur Daya Listrik Arus Bolak-Balik Satu Fasa Berbasis Personal Computer, Jurnal Tesla Vol 8.

Bird, T. (1993), Kimia Fisik untuk Universitas, Jakarta : Penerbit PT Gramedia Pustaka Utama.

Pirowarno, E., (1998), Mikroprosesor \& Interfacing, Yogyakarta : Penerbit ANDI.

Rajeswaru, (2012), Real Time Implementasi of Hydrielectric Power Plant Using PLC and SCADA, IJERA International Journal of Engineering Research and Aplications, Volume 2.

Sclater, N., (1999), Electronics Technology Handbook, United States Of America : The McGraw-Hill Companies.

Sulistyowati, R., Dedi D., (2012), Perancangan Sistem Kontrol dan Monitoring Daya Listrik Berbasis Mikrokontroler, Jurnal IPTEK: Jurusan Teknik Industri. Institut Adhi Tama. Surabaya.

Suprianto, E., (2015), Alat Pendeteksi Dini Untuk Drop Tegangan Berbasis SMS Gateway, Jurusan Teknik Elektro, Politeknik Negeri Semarang, Jurnal TELE, Vol.13, No.2.

Syam, R., (2013), Dasar - dasar Teknik Sensor, Makasar : Fakultas Teknik Universitas Hasanuddin.

Woollard, B., (2006), Elektronika Praktis, Jakarta : Pradnya Paramita, ISBN 979-408164-7.

Wulandari, C. D., Wildian. 2014. Alat Ukur Ammeter DC Tipe Non-Destructive Berbasis Mokrokontroler ATmega8535 dengan Sensor Efek Hall ACS712, Jurnal Fisika UNAND, Vol.3, No.2, April 2014, ISSN : 2302-8491.Badan Pusat Statistik, Kabupaten Tapanuli Tengah., (2012), Katalog Kecamatan Andam Dewi Dalam Rangka Andam Dewi In Figure, Pandan. 